\title{
Using Peer Collaboration Technique To Improve Students' Writing Skill Of The Eight Grade Of SMP Negeri 1 Tonra
}

\author{
Dian Riani Said ${ }^{1}$, Fahriadi Muhdar ${ }^{2}$ \\ ${ }^{12}$ Universitas Muhammadiyah Bone \\ Email: 1 dianrianisaid89@gmail.com, ${ }^{2}$ Fahrymuhdar89@gmail.com
}

\begin{tabular}{l}
\hline Article Info \\
\hline Article history: \\
Article Reseived : 12 July 2021 \\
Publication: 20 July 2021 \\
\hline Keyword: \\
Peer Collaboration, Writing \\
Skill. \\
\end{tabular}

Corresponding Author:

\section{Dian Riani Said}

Universitas Muhammadiyah Bone

dianrianisaid89@gmail.com

\begin{abstract}
The objective of this study to know the difference of students writing ability before and after being thought by related picture. Pre-experimental method was to find applied in this research with one sample group and two test, pre-test and pos-test. The population of this research was basic writing class VIII in SMP Negeri 1 Tonra Subdistrict of Tonra Bone Regency 2018-2019. The total sample of this research was 21 students from one class. Whereas, the result of computation showed that $\mathrm{t}$ observed was 9,71 and t-critical was 2.086 (at 1c.=0.05). It meant that $t$ observed was higher than $\mathrm{t}$-critic $(9,71>2.086)$. Thus, the null hypothesis was rejected, and the alternative hypothesis was accepted. It meant that there was a significant difference in students' writing ability before and after being taught by using related pictures. So it could be concluded that teaching writing by using related pictures gave better result in improving the students' writing ability of descriptive genre. There is a significant difference eight grade in students' of SMP Negeri 1 Tonra Subdistrict of Tonra Bone Regency writing ability before and after being taught by using related pictures.
\end{abstract}

This is an open access article under the Lisensi Creative Commons Atribusi-BerbagiSerupa 4.0

\section{INTRODUCTION}

\subsection{Background of the Study}

Teaching and learning a language covers four language skills, namely listening, speaking, reading, and writing. One of the four language skills is writing. According to (David, Adams. 2013), "Writing is a mental activity as a way of expressing what people think, expressing an idea, or receding communicative activities with other people". Furthermore, Farhady (2012: 320) states that writing is also a mentally advanced activities and more knowledge about many elements of language is very important in improving the writing ability. A writer first recognizes a multiplicity of linguistic signal (letters, morphemes, syllables, words, phrases, grammatical cues, discourse marks). The essay, the report and the story are some of the examples of writing activity product.

Writing compositions were supposed to (a) reflect certain standards of prescribed English rhetorical style, (b) reflect grammar, and (c) be organized in conformity with what the audience would consider to be conventional. The writer gives information, knowledge, emotion, experience, and culture by using printed texts. Most of the people in thisera use printed material to transfer the information. Newspapers, magazines, letters, brochures, 
books stories, and text books are some the media used for transferring information or message. In language education writing task is something obvious. Most students get their knowledge by writing activity. Nevertheless, some of the students still have difficulties in getting information about writing activity.

\section{REVIEW OF RELATED LITERATURE}

\subsection{Previous Study}

According to Syarifah Kurbani, Ahadi Sulissiawan, Syambassril with the title "Increasing Negotiation Text Skills Using Jigsaw Models In STtudents Of Class X IIS 2 Pontianak 6 High School 2016." The results showed an increase in the learning process by using a jigsaw model can increase students' interest and activeness in writing learning. In addition, student learning outcomes increased significantly. The average value of the first cycle is $70.96 \%$ and the second cycle is $79.35 \%$, an increase of $8.39 \%$. Based on the results of the study. The study concluded that learning to write negotiating text using a jigsaw model is very appropriate and successful with the model can improve the learning outcomes of class X IIS 2 Pontianak 6 High School.

\subsection{Review of Related Literature}

\subsubsection{Writing Skills}

The psycholinguist Eric in Kurbani (20106:319) once noted, "In a discussion of species specific" human behavior, that human beings universally learn to walk and to talk but that swimming and writing are culturally specific, learned behaviors. We learn to swim if there is a body of water available and usually only if some one teaches us. We learn to write if we are members of a literate society, and usually only if someone teaches us". According to Spandel\&Stinggis (2011-130) writing is a powerful instrument of thinking because it provides students with a way of gaining control over their thoughts. Writing shapes their perceptions of themselves and the world. It aids in their personal growth and in their effecting change on the environment. Based on the definition above, the writer assumes that the writing is a very important basic skill.

\subsubsection{Peer Collaboration}

Peer collaboration is also called group work can go wrong if it is not carefully planed, well execute, monitored troughed, and followed up in some way. Ketut Desia (2016: 178-187) states that as the writer's attention has been focused on group work differences between pair work and group work have not been emphasized. There are, in fact, some important distinction. That pair work is more appropriate than group work tasks because it is (a) short, (b) linguistically simple, and (c) quite controlled in term of the structure of the task appropriate pair activities. Meanwhile group work is characterized as follows:

a. Practicing dialogues with a partner

b. Slimly question and answer exercises

c. Performing certain meaningful substitution "drills".

d. Quick (one minute or less) brainstorming activity

e. Checking written work with each other

f. Preparation for merging with a larger group

g. Any brief activity for which the logistics of assigning group, moving furniture, and getting students into the groups is distinctive.

\subsubsection{Teaching Writing by Using Peer Collaboration}

The step of teaching writing by using peer collaboration according to Zainul (2010: 174) are as follows:

1. Introduce the technique

2. Justify the use of small groups for the technique 
3. Model the technique

4. Give explicit detailed instruction

5. Divide the class into groups

6. Check for clarification

Peer tutoring involves students helping each other learn and grow. The concept is strongly endorsed by organizations such as the National Education Association and the National Tutoring Association. Advantages of peer teaching include gains in academic achievement and stronger peer relationships. On the flip side, disadvantages of peer coaching are that peer tutoring can be ineffective and a burden for teachers if the program is simply an attempt to do more with less in response to budget cuts. Peer tutoring should supplement, not replace, quality classroom instruction.

\section{METHODOLOGY RESEARCH}

\subsection{Research Design}

In conducting the study, the writer used pre-experimental method. The method will dedicated to carrying out an experiment whether teaching writing by means of related pictures affected the students' mastery of descriptive writing or not. Later, the design of her study was one group pretest-posttest design. In this case, Frankle and Wallen (2006: 236) stated that in the one group pretest-posttest design a single group was measured or observed not only after being exposed to a treatment of some sort, but also before the treatment. Thus, the measurement of students' writing ability was held before and after teaching them by means or related pictures.

In this regard, to know the initial students' mastery of descriptive writing, the group will measured by the pretest. The group, then, will treated by means of related picture. And finally, the group was given posttest. In this regard, the result will excepted to be much better due to the treatment. In other words, related pictures hopefully generated students' comprehension of descriptive writing.

Precisely, Farhadi and Wallen (2014: 236), illustrate the pretest = posttest design in following diagram:

Where:

\begin{tabular}{cll}
\hline $\mathbf{R}$ & $\mathbf{0 1}_{1}$ & $\mathbf{X}$ \\
\hline Pre-test & Treatment & Post-test \\
\hline
\end{tabular}

$$
\begin{aligned}
& \mathrm{R}=\text { subjects are taken randomly clustered } \\
& \mathrm{X}=\text { treatment of experimental group } \\
& 01=\text { pretest of group } \\
& 02=\text { posttest of group }
\end{aligned}
$$

\subsection{Population and Sample}

\subsubsection{Population}

Arikunto (2009: 108) quotes a statement from Encyclopedia of Educational Evaluation explaining that a population is a set (collection) of all elements possessing one or more attributes of interest. Based on these statements, population in this research is all of students of the Eight Grade of SMP Negeri 1 Tonra with their various abilities. So, the number of population is 44 students. 
Table. 1. The Table of Population:

\begin{tabular}{|c|c|c|c|c|}
\hline \multirow{2}{*}{ No } & \multirow{2}{*}{ Class } & \multicolumn{2}{|c|}{ Gender } & \multirow{2}{*}{ Total } \\
\cline { 3 - 4 } & & Women & Man & \\
\hline 1 & VIIIa & 11 & 12 & 23 \\
\hline 2 & VIIIb & 8 & 13 & 21 \\
\hline 3 & VIIIc & 9 & 11 & 20 \\
\hline 4 & VIIId & 8 & 12 & 20 \\
\hline \multicolumn{2}{|c|}{ Total } & 36 & 48 & 84 \\
\hline
\end{tabular}

Data Processing : SMP Negeri 1 Tonra

\subsubsection{Sample}

Having determined the total population, then she determines the sample. Regarding to Burns (2010: 83), "A sample is any part of population regardless of whether it is representative or not". So, by cluster sampling technique the writer takes the clustered group as the sample. The sample of this research consisted of 21 students.

Table. 2. The Table of Sample

\begin{tabular}{|c|c|c|c|c|}
\hline \multirow{2}{*}{ No } & \multirow{2}{*}{ Class } & \multicolumn{2}{|c|}{ Gender } & \multirow{2}{*}{ Total } \\
\cline { 3 - 4 } & & Women & Man & \\
\hline 1 & VIII B & 8 & 13 & 21 \\
\hline \multicolumn{2}{|c|}{ Total } & 8 & 13 & 21 \\
\hline
\end{tabular}

Data Scoure : SMP Negeri 1 Tonra

\subsection{Research Instrument}

In obtaining the data, the writer uses an achievement test. The test is the subjective test on writing skill. The test is conducted twice, and both pretest and posttest are given to the group. For identifying the initial students' writing mastery, the writer holds the pretest. And finally, the writer conducts the posttest that is intended to find out the differences between students' writing ability after they are treated by using related pictures. The result of both tests are used and computed to measure the students' writing ability.

The main instrument, namely by direct communication commonly referred to as interviews and indirect communication such as test questions. As well as training in calculating negotiating text writing skills. In this case, researchers also use photo documentation tools that are used to document, teacher and student activities during the learning process using peer collaboration models about the negotiating text. Data analysis techniques are rare in data analysis techniques as follows.

1. Group data according to the problem that has been provided, shared, enhanced spelling (EYD), diction and effective sentence.

2. Analyze data and juxtapose it with relevant theories.

\subsection{Research Procedure}

Inteaching writing by using related pictures, the will take some steps as follows:

1. Firstly, the teacher greeted the students and introduces herself.

2. The teacher told the students what they are going to do that morning. She explained the procedure of the first activity and sat a time limit.

3. The teacher will show related picture concerning a current theme. Then, by making use some visual styles of related picture, students started to guest the main incident of the story.

4. Students extended their ideas into a note form, and judged quality and usefulness of ideas.

5. Students organized ideas into a mind map, spider-gram, or linear form.

6. Individually, students will write the first draft while obeying main rule of descriptive, students wrote the first draft while obeying main rule of descriptive form; give the reader a detailed description of a persons place, scene, object, or anything in the pictures. 
7. Drafts will exchanged so that students became the readers of each other work.

8. Drafts were returned and improvements were made on the basis of peer feedback.

9. A final draft is written.

10. The teacher analyzed the best produce of students' work.

11.The teacher gave an assignment concerning teaching the material that has been give.

\subsection{Technique of Data Analysis}

The procedure to analyze the data as follows:

Put the result of pretest and posttest into the table of distribution. Calculate the mean of each test. (Arikunto. 2009: 44).

a. The mean of pretest

$$
\begin{aligned}
& \text { Mx }=\frac{\sum x}{N} \\
& \text { Where : } \\
& \mathrm{Mx}=\text { mean of pretest scores } \\
& \mathrm{EX}=\text { the sum of all pretest scores } \\
& \mathrm{N} \quad=\text { the number of the tester }
\end{aligned}
$$

b. The mean of posttest

$$
\text { My }=\frac{\sum x}{N}
$$

Where :

My $=$ mean of posttest scores

$\mathrm{Ex} \quad=$ the sum of all posttest scores

$\mathrm{N}=$ the number of the testers

Looking for mean difference $(\overline{\mathrm{D}}$

$$
\overline{\mathrm{D}}=\frac{\sum D}{N}
$$

Note :

$\mathrm{D} \quad=$ main difference

$\sum \overline{\mathrm{D}}=$ sum of $\mathrm{D}$ scores

$\mathrm{N} \quad=$ number of pairs

c. The result of the pre-test and pos-test was classified in to some score as follows:

Table.3. Table Classified Score

\begin{tabular}{|c|c|c|}
\hline No & Interval & Classification \\
\hline 1 & $90-100$ & Very Good \\
\hline 2 & $80-89$ & Good \\
\hline 3 & $65-79$ & Fair \\
\hline 4 & $55-64$ & Poor \\
\hline 5 & $0-54$ & Very Poor \\
\hline \multicolumn{2}{|c|}{ Total } & - \\
\hline
\end{tabular}

\section{FINDINGS AND DISCUSSION}

\subsection{Findings}

After administering both pretest and posttest to the students, the writer got the data about their writing ability of descriptive genre. The writer then evaluated five aspects of students' writing skill; namely content, organization, vocabulary, language use, and mechanics (Adam, David, 2001). In sequence, the result of each was presented in the following tables.

To abtain the data, the researcher used a written test to know the students, writing ability by using related picture method for class VIIIB, so the researcher used multiple choise test. 


\subsubsection{Pre Test}

The following is the studenst' achievment before being taught by using related picture as pre test. Frequency and percentage of the students' score that can be seen in the table as follows:

Table. 4. The Rate Percentage of The Pre Test

\begin{tabular}{|c|c|c|c|c|}
\hline No & Interval & Frequency & Classification & Percentage \\
\hline 1 & $90-100$ & 1 & Very Good & 4,76 \\
\hline 2 & $80-89$ & 3 & Good & 14,29 \\
\hline 3 & $65-79$ & 1 & Fair & 4,76 \\
\hline 4 & $55-64$ & - & Poor & - \\
\hline 5 & $0-54$ & 16 & Very Poor & 76,19 \\
\hline \multicolumn{2}{r|}{ Total } & 21 & - & 100 \\
\hline
\end{tabular}

Based on the table above. The result of the eksperiment group shows that there were $1(4,76 \%)$ students got very good, $3(14,29)$ students got good, $1(4,76)$ students got fair, $16(76,19)$ students got very poor. The table above shows that the rate percentage of the students score on pre-test was in very poor classification because there was $16(76,19)$ students.

Then to clarify the data from the categorization frequency table, the data of student learning outcomes in the pretest class is presented in the form of a beam diagram, as follows:

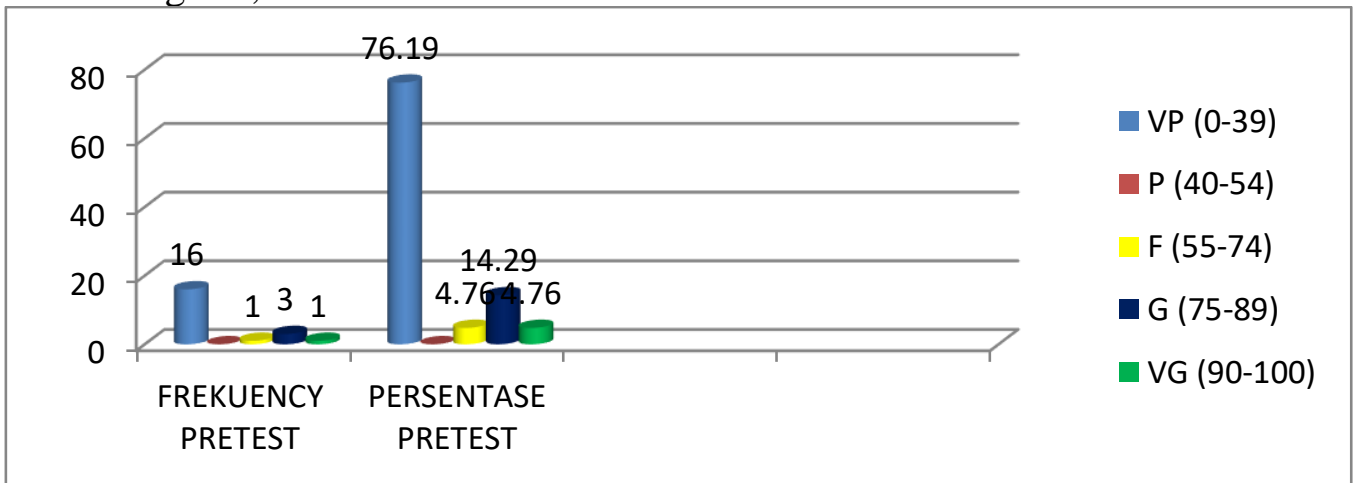

\subsubsection{Pos Test}

Diagram 1. Classification Score Pretest

The following is the studenst' achievment before being taught by using related picture as Post test. Frequency and percentage of the students' score that can be seen in the table os follows:

Table. 5. The Rate Percentage of The Post Test

\begin{tabular}{|c|c|c|c|c|}
\hline No & Interval & Frequency & Classification & Percentage \\
\hline 1 & $90-100$ & 6 & Very Good & 28,58 \\
\hline 2 & $80-89$ & 5 & Good & 23,80 \\
\hline 3 & $65-79$ & 8 & Fair & 38,10 \\
\hline 4 & $55-64$ & 2 & Poor & 9,52 \\
\hline 5 & $0-54$ & - & Very Poor & - \\
\hline \multicolumn{2}{r}{ Total } & 21 & - & 100 \\
\hline
\end{tabular}

Scource : Primary Data 2020.

Based on the table above. The result of the eksperiment group shows that there were $6(28,58 \%)$ students got very good, $5(23,80 \%)$ students got good, 8 $(38,10 \%)$ students got fair, $2(9,52 \%)$ students got poor. Then to clarify the data from the categorization frequency table, the data of student learning outcomes in the pretest class is presented in the form of a beam diagram, as follows: 


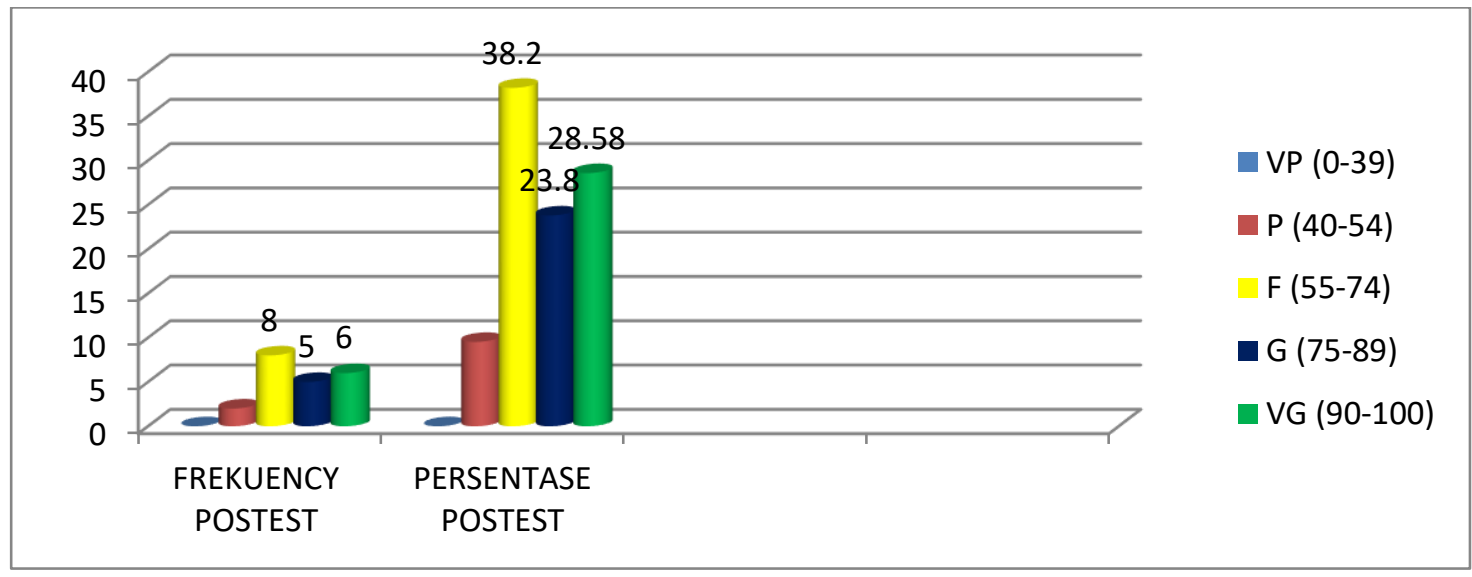

Diagram 3.2. Classification Score Postest

4.2. The mean score and standard deviation of the test that described in the following table.

Table.6. Mean score and standard deviation of students

\begin{tabular}{llcc}
\hline No & \multicolumn{1}{c}{ Test } & Pre Test & Post Test \\
\hline 1 & Mean Score & 45,95 & 79,29 \\
2 & Standard deviation & 18,84 & 82,17 \\
\hline
\end{tabular}

Scource : Primary Data 2020.

The table above showed that the mean score of students' pretest was 45,95 and the mean of score postest was 79,29. It can be compared that the mean score of students' postest higher than the mean score of students' pretest. It means that the mean score of the students' postest was greater than the mean score of the students' pretest. The standard deviation of pretest was 18,84 and standard deviation of postest was 82,17 . The standard of pretest was smaller than the standard deviation of pretest, which indicated that the range of students' score is better.

\subsubsection{The $\mathbf{T}$ - test of Significance}

In order to know whether or not mean score is different from the two variable (pretest and postest), the $\mathrm{t}$ - test statical analysis for non independent sample was applied. The following is the table that shows the result of the calculation.

Table .7. The t-test value of the students

\begin{tabular}{cc}
\hline $\mathrm{T}-$ test Value & $\mathrm{T}-$ table Value \\
\hline 9,71 & 2,086 \\
\hline Scource $:$ Primary Data 2020.
\end{tabular}

From the table above, the t-test 9,71 . It was greater than the table value $(2,086)$ by the level of significan $(0,05)$ with degree of freedom ( $n$-the number of variable). It indicates that the difference between these mean was statisticallysignificant, it also in dicate the null hypothesis (Ho) was rejected and the alternative hypothesis $\left(\mathrm{H}_{1}\right)$ was accepted.

To find out the degree of freedom (df), the researcher used the following formula :

$$
\begin{aligned}
& \text { df }=\mathrm{N}-1 \\
& \mathrm{df}=21-1 \\
& \mathrm{df}=20
\end{aligned}
$$

Where $\mathrm{N}=$ Number of subject $(20)$

\subsection{Discussion}

In the analysis section, the researcher explained that the mean score on post-test ( $79,29)$ was greather thab pre-test $(45,95)$. It can be concluded that there was a significant 
difference of both test. It was proved by t-test statistical are the level of significance 0,05 and degree of freedom (n-number of variable) which found that t-test value $(9,71)$ was greater than t-table $(2,086)$ or t-test, $9,71>2,086$. It indicates that the difference between these mean was statistically significant, it also in dicate the null hypothesis (Ho) was rejected and the alternative hypothesis $\left(\mathrm{H}_{1}\right)$ was accepted. The result in the discussion above indicate that the use related picture method was significantly improved writing in SMP Negeri 1 Tonra Bone Regency.

Based on the finding in this study, the researcher interpreted that the used of related picture the use of related picture to improve student's writing ability at the eighth grade of SMP Negeri 1 TonraBone Regency. It was assumed that the students' ability in learning vocabulary before being taught throught related picture method was in the enough level. After the treatment, the students' achievement in vocabulary improved. This condition means that teaching writing through related picture method could improved their writing of descriptive text.

\section{CONCLUSIONS AND SUGGESTIONS \\ 5.1.Conclusion}

Having conducting research in Class VIII of SMP Negeri 1, Tonra Bone Regency, the writer draws the conclusion that teaching writing using related images gives better results in improving students' ability to write descriptive text. Thus, there is a significant difference in writing achievement between students who are taught using peer collaboration and those who are not. The advantages are as follows:

1. The english writing at the Eighth Grade of SMP Negeri 1 Tonra Bone Regency students in the academic yaer 2018/2019 befor using the related picture strategy in english teaching learning process were still in low level. In the other word, the students have very poor writing of descriptive text. It seems from the result of pretest mean was 45,95 still have the score less and post test mean was 79, 29 have the score good.

2. The process of teaching Writing using the related pictures method was almost all of the students were enthusiastic to follow the lesson. It seemed at the result of observation in the class that was most of students interested in learning process and they were more active. The students achievement of writing has improved through related pictures in teaching learning process. When it compared between pre test and post test, they know that the students score in post test was greater than pre test. Furthermore, the result of thetest calculation in pre test mean was 18,84 and post test mean was 82,17 table with $\mathrm{N}=$ 21. Furthermore, in other words, it was effective to teach wriritngthrough related pictures method to the Eighth Grade of SMP Negeri 1 Tonra Bone Regency.

\subsection{Suggestions}

In line with the conclusion above, writer drew some suggestions to both teachers, students, and also to principal as follows:

1. For the Teachers

As writing was an independent, solitary activity without any situational context, the possibility of interaction, not the benefit of feedback, the teacher stimulated the students' creativity for producing ideas as much as possible by using varied media, such as related pictures. Then, for eliminating students' mistakes in producing the ideas, the teacher remained as a consultant-like during the writing process. So, the teacher didn't inhibit students' activity, but gave them support for a better writing product.

2. For the students

In achieving writing skill, students regularly learnt to write by means varied learning media of writing. In this case, the medium referred to related pictures of 
descriptive text. The pictures provided some visual styles featuring with the mean incident of the story. The teacher conveyed some additional information regarding to detailed description of a person, place, scene, or object of the pictures.

3. For the principal

Since acquiring writing ability means students regularly learn to write by means of varied learning media of writing, they are demanded to learn intensively and simultaneously. And through educational policy, the, principal has to provide his students with fully support a conducive environment that giving a lot of opportunities to them to learn and practice the writing ability.

\section{BIBLIOGRAPHY}

Adams, David. 2013. Writing Better Reports. Michigan: Department of Civil \& Environmental Engineering Michigan State University

Farhadi.2014. Methodology Research. Bandung: Gramedia.

Ghazi Ghaith. 2013. Page created on Feb. 6, 2002. Last update on Feb. 11, 2004 Copyright 2004.Back to Nada's Homepage Back to "Teaching Writing" Page.

Greenberg \&Rath. 1985. The Development and Validation of the TOEFL Writing Test: A Discussion of TOEFL Research Report 15 and 19 Tesol Quarterly, 20 (3), 531544.

Hatch \&Farhady, 2012.Discourse and Language Education.New York: Cambridge: University Press.

Kurbani, Syarifah, AhadiSulissiawan and Syambassril. 2016. Increasing Negotiation TextSkills Using Jigsaw Models In STtudents Of Class X IIS 2 Pontianak 6 High School.

Lado, Robert. 1964. Skill of Language. New York: Longman.

Spandel and Stiggin. 2011. Learning Strategis in Second Language Acquisition. New York: Cambridge University Press.

Tristiantari, Ketut Desia. 2016. Cooperative Integrated Reading Composition Lesson Study LearningModel ToImproveReading Skills And Writing.

Zainul, and Nasution. 2010. Language Learning and Teaching. Jakarta: PT.Pustaka Balai 